\title{
Pramoedya Ananta Toer di Bawah Cahaya Claude Levi-Strauss: Analisis Struktural Roman Arok-Dedes
}

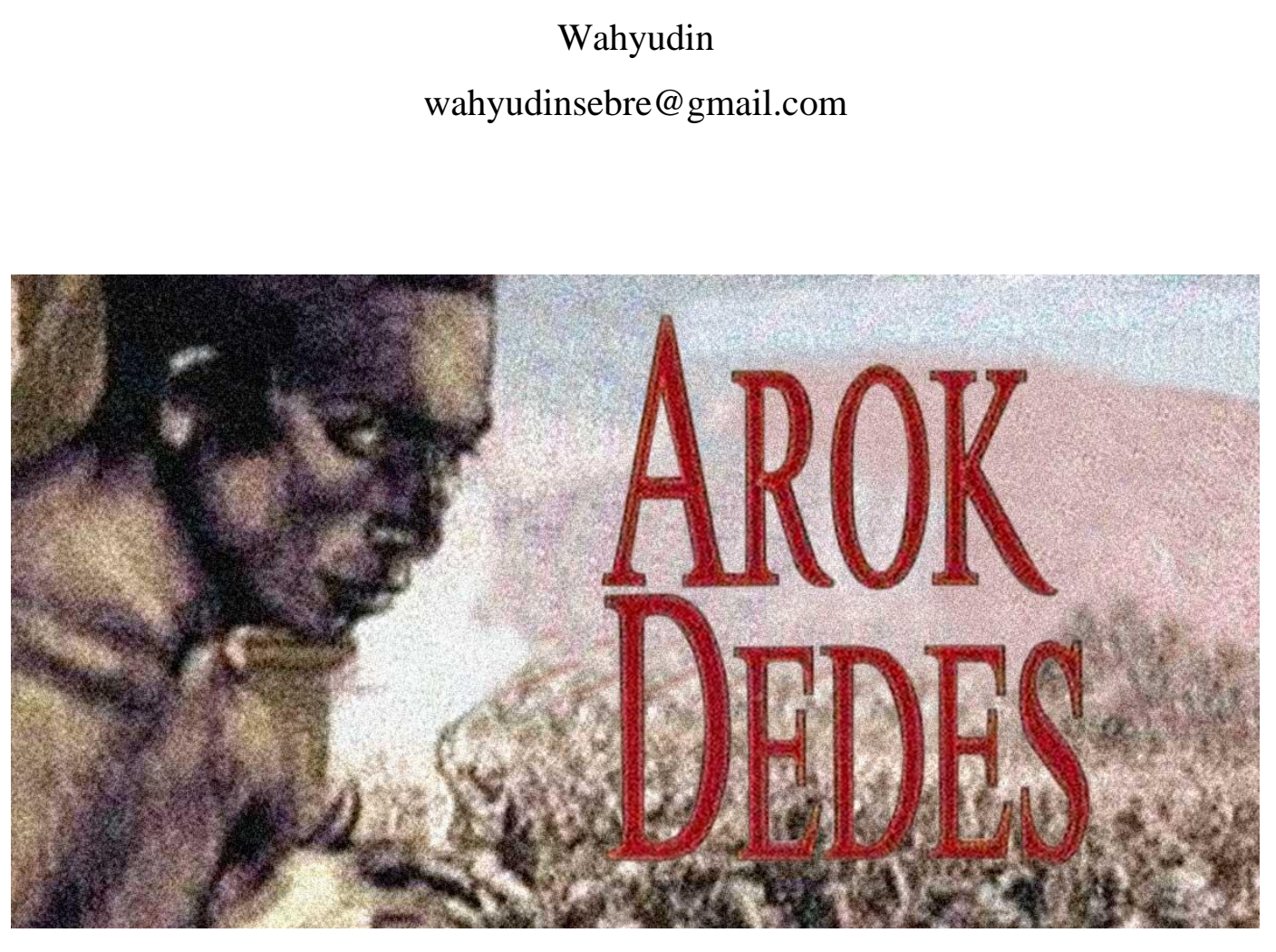

Potongan sampul Arok-Dedes Pramoedya Ananta Toer

(Sumber: histroria.id)

\begin{abstract}
Abstrak
Sebuah roman sejarah pada dasarnya adalah mitos dan legenda yang memakai baju modern. Roman sejarah ini tidak hanya menarik dari segi teknik bertuturnya, tapi juga isi dan pesannya yang menantang untuk dibedah dengan pisau analisis struktural seperti yang dikembangkan oleh Claude Levi-Strauss. Arok-Dedes mengisahkan peristiwa kudeta pertama dalam sejarah Nusantara. Pramoedya merajut struktur narasi atau relasi penceritaannya berdasarkan kecenderungan ideologi yang dianutnya. Tokoh-tokoh yang terlibat dalam pertikaian yang berlangsung menurut oposisi biner. Misalnya, oposisi Tunggul Ametung yang
\end{abstract}


sudra-satria dengan kaum brahmana dimediasi oleh Ken Arok yang sudra-satriabrahmana. Perspektif itu tampaknya sejalan dengan pandangan Levi-Strauss tentang mitos. Menurutnya, setiap mitos merupakan suatu upaya mengingat kembali hal-hal yang telah lewat. Lebih dari itu, keberadaan mitos dalam suatu masyarakat adalah dalam rangka mengatasi atau memecahkan berbagai kontradiksi empiris yang tidak terpahami atau terpecahkan oleh nalar manusia.

Keywords: analisis struktural, mitos, kudeta, ideologi, oposisi biner, roman sejarah.

Wahyudin adalah penulis dan kurator seni rupa. Belajar etnografi di Program Studi Antropologi Pascasarjana UGM Yogyakarta (Angkatan 1999). Buku seni rupanya yang sudah terbit adalah "Bergerak dari Pinggir" (2018), "Omong Kosong di Rumah Seni Cemeti” (2019), "Bertandang ke Galeri (2020), dan "Oei Hong Djien: Delapan Puluh nan Ampuh” (2021).

\section{Pendahuluan}

Jakarta, Minggu, 30 April 2006, pukul 09.15 WIB: Pramoedya Ananta Toer wafat. Pada sore hari itu juga ia dikuburkan di Taman Pemakaman Umum Karet Bivak, Jakarta. Penyair Goenawan Mohamad datang ke pemakaman sastrawan kelahiran Blora, Jawa Tengah, 6 Februari 1925, itu. Sepekan kemudian, eksponen dan penandatangan "Manifes Kebudayaan” itu menulis, antara lain, sebagai berikut:

"Jasad Pramoedya Ananta Toer diturunkan ke liang lahat. Tanah diuruk. Saat itu sekitar pukul empat sore, separuh langit Jakarta gelap, udara hamil hujanseakan-akan persiapan adegan akhir di Karet Bivak itu. Sebuah lagu tiba-tiba terdengar, dinyanyikan bersama dengan khidmat, terutama oleh mereka yang muda: 
Di negri permai ini

Berjuta Rakyat bersimbah rugah

Anak buruh tak sekolah

Pemuda desa tak kerja ...

Mereka dirampas haknya

Tergusur dan lapar

Sore itu, hujan mulai jatuh di pemakaman. Orang-orang mengangkat tangan kiri memberikan salut penghabisan kepada Pramoedya Ananta Toer. Internasionale dinyanyikan. Sejarah tak selamanya murung, ternyata, meskipun tak selamanya ceria."

Di antara yang murung dan yang ceria itu, kita tahu, pada penghujung 1999, Pramoedya Ananta Toer telah "mewariskan" karya terakhirnya, sebuah roman sejarah, Arok-Dedes.

\section{Roman dan Mitos}

Sebagaimana diungkapkan Joesoef Isak, sahabat karib Pramoedya Ananta Toer semasa menjadi tahanan politik di Pulau Buru, Arok-Dedes mengisahkan peristiwa kudeta pertama dalam sejarah Nusantara, "kudeta ala feodal Jawa, licik munafik, tidak terbuka, lempar batu sembunyi tangan."

Kalimat yang diberi tanda petik itu sesungguhnya adalah perkataan Pramoedya yang dikutip Isak dalam pengantar roman sejarah ini (hlm. viii) untuk menegaskan bahwa dalam sejarah kerajaan-kerajaan di Nusantara perebutan kekuasaan dengan cara kudeta sudah pernah terjadi pada awal abad ke-13 ketika Ken Arok

\footnotetext{
${ }^{1}$ Selengkapnya baca Goenawan Mohamad, "Pramoedya", Tempo, 8-14 Mei 2006. Tulisan ini terbit ulang dalam Goenawan Mohamad (2011). Catatan Pinggir 8. Jakarta: Pusat Data dan Analisa Tempo. h. 189-192.
} 
menggulingkan kekuasaan Tunggul Ametung dari singgasana kekuasaannya di Tumapel pada 1220 .

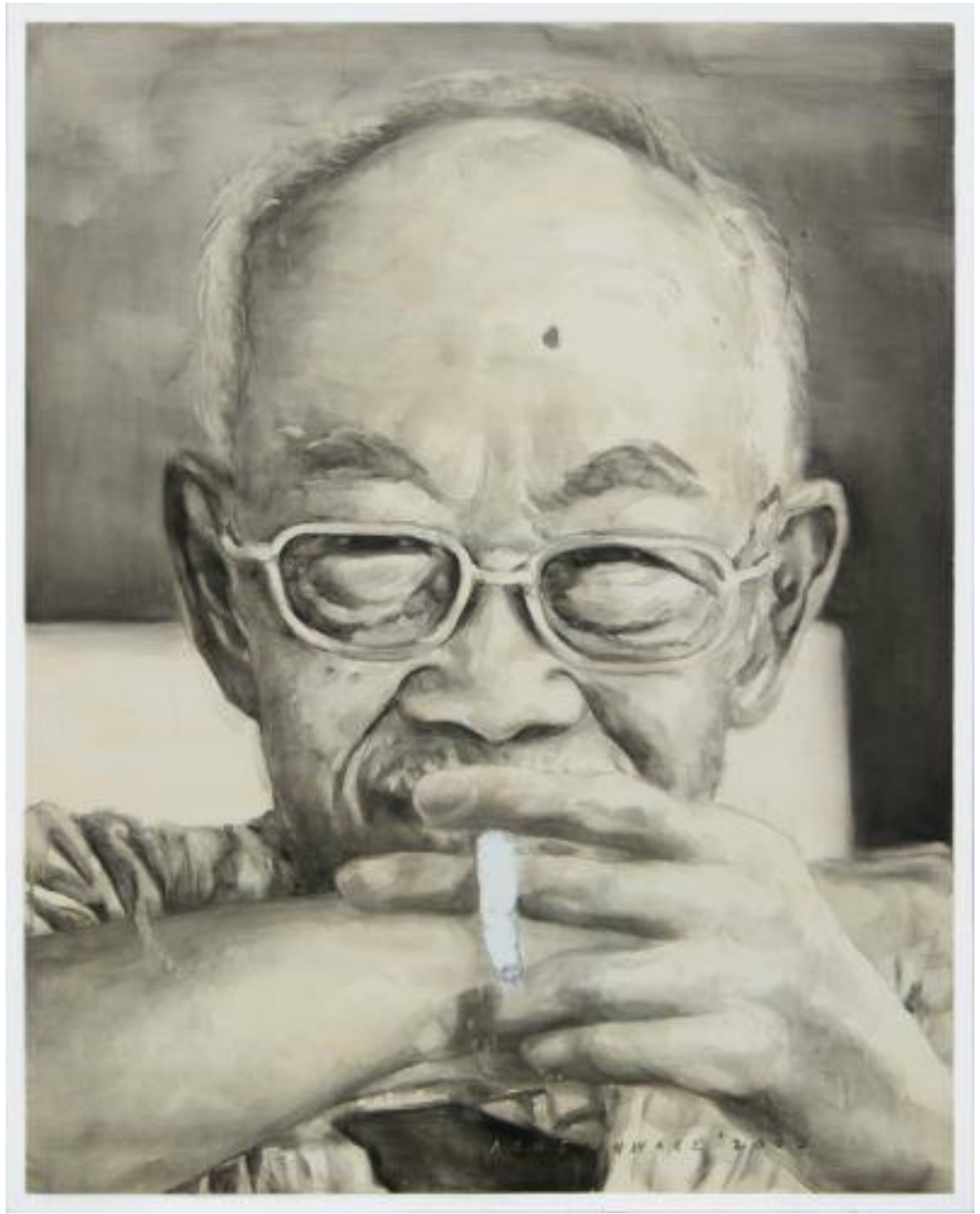

Agus Suwage, I Want to Live Another Thousand Years Series Pram, 2006, cat minyak di kanvas, $120 \times 150$ sentimeter

(Sumber: Indonesian Visual Art Archive) 
Tapi, bukan itu maksud sebenarnya penulisan roman sejarah ini. Menurut Pramoedya, roman sejarah ini ditulis dalam "usaha membangun basis sosial-historis bagi sejarah hidup Arok dan Dedes yang mulai membukakan peradaban baru di Jawa. Makin meninggalkan pengaruh Hindu, untuk data sejarah yang banyak kali terdengar kedongeng-dongengan.”

Pernyataan tersebut mengesankan suatu ambisi yang kuat-dan seperti banyak ambisi yang kemudian tertoreh menjadi kenyataan, sering kali membuat kita tercengang-dari seorang pengarang gaek yang hidupnya terlampau sering dikecewakan oleh kekuasaan pongah dan gemar memberangus karya-karyanya.

Namun, hidup baginya bukanlah berarti hanya untuk menunda kekalahan dan kemudian mati, melainkan untuk "memberikan kesaksian kepada sesuatu yang dianggap sia-sia dan berjuang biarpun hanya dengan tulisan."2

Sebagai seorang pengarang, Pramoedya sadar betul bahwa tulisan-tulisannya suatu ketika akan mengutukinya dan menjadi hakim sekaligus jaksa yang bakal memburunya seumur hidup, sebagaimana peringatan yang pernah disampaikan seorang sahabatnya sewaktu mereka menjadi tahanan militer Belanda pada 1947 — dan peringatan itu telah terbukti kebenarannya. ${ }^{3}$ Barangkali itulah salah satu hikmah dari kepengarangannya yang — hingga hayat dikandung badan — kerap mengambil jalan yang berbeda dan tidak populer.

Roman sejarah Arok-Dedes adalah salah satu bukti konkret dari sikap kepengarangannya yang tidak populer itu. Berbeda dengan para sejarawan yang percaya bahwa referensi yang paling otoritatif tentang riwayat hidup Ken Arok

\footnotetext{
${ }^{2}$ Pernyataan ini diilhami oleh kata-kata Minke, tokoh utama novel Bumi Manusia (1980): "Ya, Ma, kita sudah melawan, Ma, biarpun hanya dengan mulut". Menurut seorang pengamat sastra, katakata tersebut mencerminkan semangat tulisan Pramoedya - yaitu berjuang. Selengkapnya, lihat I Gusti Agung Ayu Ratih, "Rushdi dan Pramoedya, Bersimpangnya Narasi tentang Bangsa", dalam Kalam-edisi 6, 1995, h. 48-73.

${ }^{3}$ Periksa Pramoedya Ananta Toer, "Perburuan dan Keluarga Gerilya", dalam Pamusuk Eneste (ed.). (1984). Proses Kreatif II: Mengapa dan Bagaimana Saya Mengarang. Jakarta: Gramedia. h. 52-53.
} 
adalah Pararaton atau Kitab Raja-Raja, ${ }^{4}$ Pramoedya mengambil bahan penulisan roman sejarah ini dari kitab Lubdaka karya Mpu Tanakung dari relief Tugu Kemenangan Arok yang ada dalam kompleks Candi Singasari atau Candi Tumapel. Menurutnya, bahan-bahan itu merupakan materi sejarah yang paling adekuat tentang riwayat Arok-Dedes. Sayangnya, saya tak beroleh keterangan mengenai cara Pramoedya mengakses materi sejarah tersebut, dan argumentasi yang mendukung penolakannya menggunakan Pararaton dalam roman sejarah ini.

Lepas dari persoalan itu, perlu segera saya tekankan di sini, kehadiran roman sejarah ini dalam konteks diskursus ilmu-ilmu sosial-humaniora di Indonesia merupakan kontribusi berharga yang dapat memperkaya koleksi kepustakaan yang penting dan bermutu.

Tak kurang dari itu, pada hemat saya, roman sejarah ini tidak hanya menarik dari segi teknik bertuturnya, tapi juga isi dan pesannya yang menantang untuk dibedah dengan pisau analisis struktural yang dikembangkan oleh Claude Levi-Strauss.

Ada sejumlah alasan yang mendasari pernyataan tersebut-yang juga menjadi inspirasi saya menulis esai ini. Pertama, sebuah roman sejarah pada dasarnya adalah mitos dan legenda yang memakai "baju” modern. Itu sebabnya, menurut A. Teeuw dalam Sastra Baru Indonesia (1980: 79), ia lebih menarik dari segi antropologi daripada segi kesusastraan modern.

Pernyataan itu mengingatkan saya pada pendapat Levi-Strauss tentang roman dalam wawancaranya dengan majalah Spiegel (1971). Di situ ia mengungkapkan:

\footnotetext{
${ }^{4}$ Lihat Pararaton, edisi dwi-bahasa, Kawi-Indonesia, terj. Ki. J. Padmapuspita (1966). Yogyakarta: Taman Siswa. Salah satu komentar mengenai kitab ini dapat disimak dalam Denys Lombard (1996). Nusa Jawa: Silang Budaya 3. Jakarta: Gramedia dan Forum Jakarta-Paris. h. 145-146. Juga komentar C. C. Berg yang dikutip M. C. Ricklef (1991). dalam Sejarah Indonesia Modern, terj. Dharmono Hardjowidjono. Yogyakarta: UGM Press. h. 25-26.
} 
"Sering saya menghabiskan seluruh pekan dengan mendengarkan siaran langsung Wagner dari Bayreuth. Dalam jilid keempat dan terakhir dari Mythologies (1971) yang diterbitkan dengan judul I'homme nu (Manusia Telanjang), saya menjelaskan alasannya. Saya mengatakan bahwa pada saat runtuhnya mitologi sebagai bentuk ekspresi yang dominan, semua struktur pikiran mitis diambil alih oleh musik. Isi dan pesannya beralih ke roman, sedangkan bentuk mitos diambil alih oleh musik."

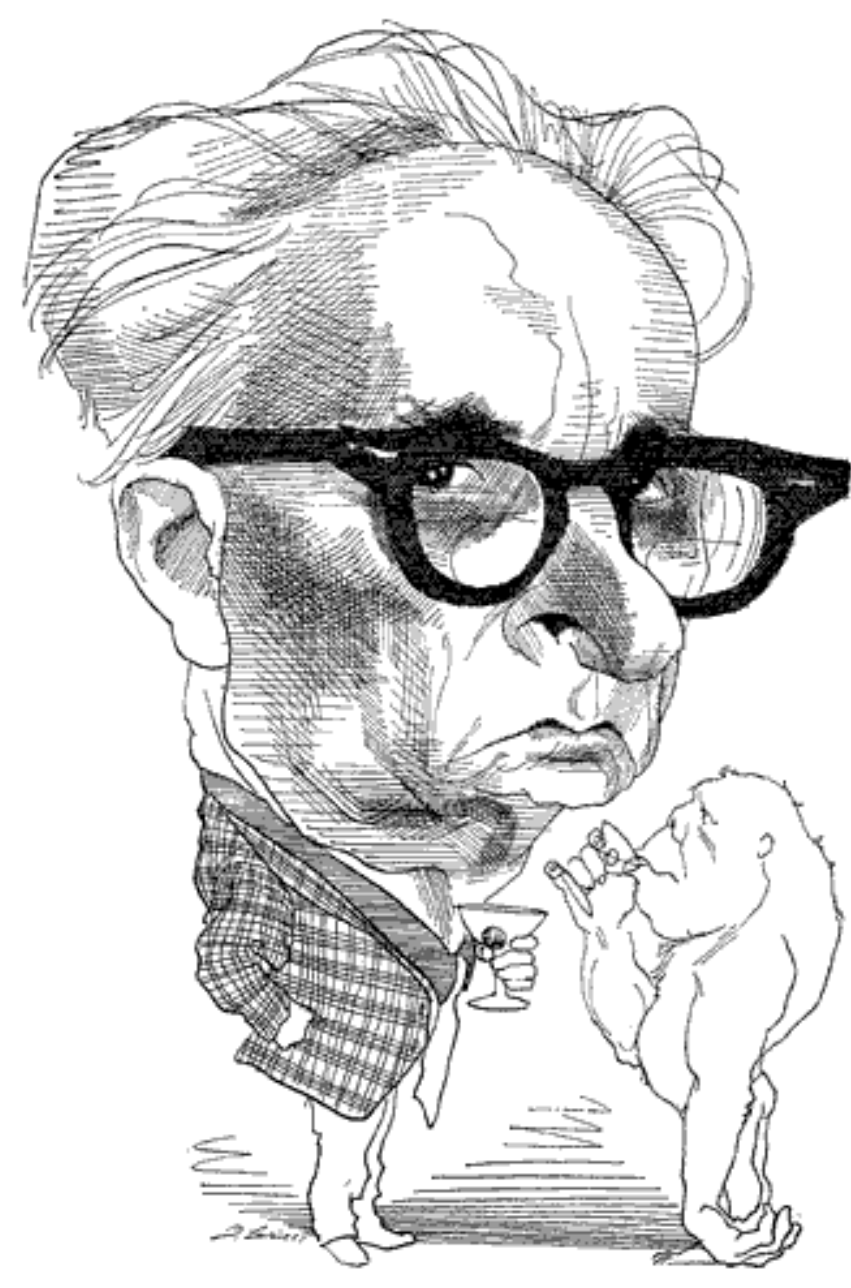

Claude Lévi-Strauss

Karikatur Claude Levi-Strauss

(Sumber: iniziativalaica.it) 
Sebagaimana diketahui, dalam antropologi pembahasan mengenai mitos dan legenda masuk ke dalam kajian folklore. Menurut James Danandjaja (1997: 66), seperti halnya mitos, legenda adalah cerita prosa rakyat, yang dianggap oleh empunya cerita sebagai suatu kejadian yang sungguh-sungguh terjadi. Tapi, berbeda dengan mitos, legenda bersifat sekuler (keduniawian), terjadinya pada masa yang belum lampau, dan bertempat di dunia yang kita kenal sekarang.

Dalam konteks itu, mengikuti penggolongan Jan Harold Brunvand (via Danandjaja, 1997), ${ }^{5}$ kisah Arok-Dedes tergolong ke dalam legenda perseorangan (personal legends), yaitu cerita mengenai tokoh-tokoh tertentu yang dianggap oleh empunya cerita benar-benar ada dan terjadi.

Kedua, jauh sebelum roman sejarah ini selesai ditulis pada 1976, dan diterbitkan 23 tahun kemudian, ia telah dipublikasikan oleh Pramoedya dengan cara melisankannya di hadapan para tahanan politik Pulau Buru. Itu berarti dalam membawakan roman ini Pramoedya berlaku sebagai tukang cerita atau pendongeng. ${ }^{6}$

Dengan begitu, kita bisa memposisikannya sebagai empunya cerita yang membangun tema, latar cerita (setting), perwatakan tokoh-tokohnya (characterization), alur cerita (plot), dan ketegangan cerita (suspense) berdasarkan interpretasinya terhadap materi sejarah yang sudah ada, seperti yang sudah diungkapkan di awal esai ini, serta merajut struktur narasi atau relasi penceritaannya berdasarkan kecenderungan ideologi yang dianutnya. Dalam posisi itu kita bisa menyamakannya seperti seorang Syaman yang menjelmakan sebuah mitos ke dalam teks naratif.

\footnotetext{
${ }^{5}$ Jan Brunvand menggolongkan legenda menjadi empat kelompok: (1) legenda keagamaan, (2) legenda alam gaib, (3) legenda perseorangan, (4) legenda setempat. Penjelasan komprehensifnya dapat dibaca dalam Danandjaja (1997). Folklor Indonesia: Ilmu Gosip, Dongeng, dan lain-lain. Jakarta: Pustaka Utama Grafiti. h. 67-83.

${ }^{6}$ Laku yang sama diperankannya juga saat membawakan roman sejarah Arus Balik (1995). Mengenai hal ini baca A. Teeuw (1997). Citra Manusia Indonesia dalam Karya Sastra Pramoedya Ananta Toer. Jakarta: Pustaka Jaya. h. 297.
} 


\section{Imaji dan Struktur}

Dalam prakata roman sejarah Arok-Dedes (hlm. 3), Pramoedya Ananta Toer mengungkapkan bahwa "cerita Arok-Dedes terjadi dalam zaman leluhur sudah terbiasa memerintah, berpolitik, berintrik, biasa menggulingkan dan membangun negara — suatu kondisi yang mungkin menyebabkan orang Indonesia dewasa ini menganggap terlalu maju untuk zamannya."

Tapi Pramoedya segera menyangkal anggapan tersebut. Menurutnya, "Taktiktaktik Arok sendiri telah dipraktikkan berulangkali, baik untuk menggulingkannya sendiri oleh anak tirinya Anusapati, Jayakatwang dalam menggulingkan Kertanegara, maupun oleh turunan Arok keempat, Raden Wijaya, dalam menggulingkan dua musuh sekaligus, Jayakatwang dan balatentara Kubilai Khan pada tahun 1293.”

Saya kira, Pramoedya memahami itu benar ketika menghubungkan roman ArokDedes dengan tanggapan yang diberikan oleh sebagian masyarakat Indonesia sekarang yang tak beranjak jauh dari stereotipe tentang tokoh-tokoh mitologi atau legenda, yang fungsinya tak lebih dari sekadar cerita pengantar tidur.

Oleh karena itu, menjadi beralasan jika ia bermaksud menempatkan roman sejarah ini dalam perspektif "menyoroti sesuatu yang jauh dengan cahaya dari suatu yang dekat".

Perspektif itu tampaknya sejalan dengan pandangan Levi-Strauss dalam Structural Anthropology (1963: 204) tentang mitos. Menurutnya, setiap mitos merupakan suatu upaya mengingat kembali hal-hal yang telah lewat. Lebih dari itu, keberadaan mitos dalam suatu masyarakat adalah dalam rangka mengatasi atau memecahkan berbagai kontradiksi empiris yang tidak terpahami atau terpecahkan oleh nalar manusia. 
Oleh karena itu, menjadi beralasan jika Heddy Shri Ahimsa-Putra dalam "LeviStrauss di Kalangan Orang Bajo: Analisis Struktural Makna dan Cerita Orang Bajo” (1997) mengatakan bahwa mitos sebagai "mimpi kolektif" suatu masyarakat merupakan "jendela" untuk melongok ke dalam batin mereka. Di sinilah antropologi struktural dapat diasosiasikan sebagai "cahaya dari suatu yang dekat" yang berfungsi menyorot mitos, dongeng, dan legenda sebagai “sesuatu yang jauh”.

Sebagai "cahaya dari suatu yang dekat"-antropologi struktural bermaksud mencari hal atau unsur invarian yang ada di bawah permukaan penampilan rupa yang beraneka ragam. Orientasi teoritik ini dilatarbelakangi oleh pemikiran bahwa mitos, misalnya, sebagai sebentuk ekspresi pemikiran primitif, memiliki struktur yang bersifat dialektis. Levi-Strauss mengatakan (via Mary Douglas, 1969) sebagai berikut:

"The structure of myth is a dialectic structure in which opposed logical position are stated, the oppositions mediated by restatement, which again, when its internal structure becomes clear, gives rise to another kind of opposition, which in its turn is mediated or resolved, and so on."

Jelasnya, dari sana ditampilkan oposisi dan kontradiksi tertentu: lakilaki:perempuan; endogami:eksogami; kakak:adik; bumi:langit; dan seterusnyadan kemudian ada semacam penengahan atau pemecahan (David Kaplan dan Robert A. Manners, Teori Budaya, 1999: 240).

Dengan kata lain, sebagaimana dikemukakan Octavio Paz dalam Levi-Strauss: Empu Antropologi Struktural (1997), dalam struktur mitos terdapat berbagai peristiwa yang saling bertentangan dalam bentuk oposisi-oposisi meskipun tidak selalu kentara-dan dalam ketidakkentaraan itu tersimpan apa yang disebut "amanat yang dikodekan". 
Pertanyaannya: bagaimana mitos "menerangkan" kontradiksi-kontradiksi yang ada dalam dirinya? Jawab Levi-Strauss (via Octavio Paz, 1997: 27), mitos memiliki objek berupa penyajian suatu model logis untuk menerangkan sekaligus memecahkan suatu kontradiksi — sesuatu yang tidak dapat dilakukan seandainya kontradiksi itu nyata.

Octavio Paz menyebut "model logis" itu dengan istilah term-term penengah atau mediator-suatu inkarnasi proposisi-proposisi logis yang memungkinkan kontradiksi-kontradiksi diluluh-larutkan atau diterobos.

Ilustrasinya, dalam roman Arok-Dedes akan banyak kita temukan tokoh-tokoh yang terlibat dalam pertikaian yang berlangsung menurut oposisi biner (dua posisi utama yang saling bertubrukan) dan mediator yang muncul untuk menengahi pertentangan itu. Misalnya, oposisi Tunggul Ametung yang sudra-satria dengan kaum brahmana dimediasi oleh Ken Arok yang sudra-satria-brahmana.

Selain itu, akan ditemukan juga sejumlah homolog atau persamaan-persamaan yang berfungsi sebagai "benang merah" yang menghubungkan satu tokoh dengan tokoh yang lain. Contohnya, oposisi laten Ken Dedes terhadap Tunggul Ametung homolog dengan sikap kooperatif Ken Arok atas Tunggul Ametung.

\section{Raja Idaman: Kekuasaan dan Moral}

Kudeta, saya kira, adalah kata yang tepat untuk merepresentasikan "cara aneh" Arok untuk menggulingkan kekuasaan Tunggul Ametung. Dengan kata itu, saya mendapatkan semacam kerangka untuk membaca secara keseluruhan peristiwa yang terjadi pada 1220 itu.

Begitulah, penggulingan kekuasaan itu terjadi dari "infiltrasi ke dalam suatu segmen aparatus negara yang kecil tetapi menentukan, yang kemudian digunakan untuk mengambil-alih Pemerintah dari kendali unsur-unsur lainnya." 
Perlu diketahui, itulah pengertian formal dan fungsional kudeta dalam buku pegangan tentang teori dan praktik penggulingan kekuasaan (lihat Edward Luttwak, Coup d'Etat: A Practical Handbook, 1976).

Dari situ, satu hal penting yang perlu digarisbawahi, kudeta sesungguhnya merupakan suatu tindakan politik yang tak mengacuhkan "moralitas kekuasaan" karena Ken Arok dan kelompoknya, misalnya, tak jarang menggunakan metodemetode "menghalalkan segala macam cara" dengan penggunaan kekerasan untuk mencapai tujuannya menggulingkan kekuasaan Tunggul Ametung.

Pertanyaannya: masih perlukah "moralitas kekuasaan” itu kita bicarakan di sini? Saya kira perlu. Sebab, hal itu berhubungan erat dengan apa yang sekarang sering dibicarakan orang sebagai "problem legitimasi”. Artinya, sebuah kekuasaan yang didapat dengan cara seperti itu akan menjadi sah apabila ia dilegitimasi oleh masyarakat setempat di mana peristiwa itu terjadi.

Tak pelak lagi, kudeta di Tumapel adalah peristiwa perebutan kekuasaan yang berkaitan erat dengan "problem legitimasi” tersebut. Kudeta Ken Arok pun seketika sah setelah dilegitimasi oleh Brahmana Lohgawe yang-dalam konteks sosial masyarakat Jawa pada masa itu—merupakan representasi tertinggi masyarakat dan negara.

Dengan demikian, pada situasi tertentu dalam babakan sejarah orang Jawa, kekuasaan itu bisa diperoleh secara sah atau tidak sah-dan bisa dipergunakan secara baik atau tidak baik (periksa Franz Magnis-Suseno, Etika Jawa, 1996: 110111).

Ternyata, untuk menjadi seorang "Raja Idaman"-dan ini berbeda dengan kepercayaan orang Jawa umumnya — itu bisa digapai tanpa campur tangan kekuatan adikodrati. 


\section{Kepustakaan}

[1] Claude, Levi-Strauss (1963). Structural Anthropology. London: Basic Books.

[2] Danandjaja (1997). Folklor Indonesia: Ilmu Gosip, Dongeng, dan lain-lain. Jakarta: Pustaka Utama Grafiti.

[3] Goenawan Mohamad (8-14 Mei 2006). "Pramoedya", Tempo, 8-14 Mei 2006.

[4] Goenawan Mohamad (2011). Catatan Pinggir 8. Jakarta: Pusat Data dan Analisa Tempo.

[5] I Gusti Agung Ayu Ratih (1995). "Rushdi dan Pramoedya, Bersimpangnya Narasi tentang Bangsa”. Kalam-edisi 6.

[6] Ki. J. Padmapuspita (terj.) (1966). Pararaton. edisi dwi-bahasa, Kawi-Indonesia. Yogyakarta: Taman Siswa.

[7] Lombard, Denys (1996). Nusa Jawa: Silang Budaya 3. Jakarta: Gramedia dan Forum Jakarta-Paris.

[8] Luttwak, Edward (1976). Coup d'Etat: A Practical Handbook. Cambridge: Harvard University Press.

[9] Magnis-Suseno, Franz (1996). Etika Jawa. Jakarta: Gramedia.

[10] Pamusuk Eneste (ed.) (1984). Proses Kreatif II: Mengapa dan Bagaimana Saya Mengarang. Jakarta: Gramedia.

[11] Paz, Octavio (1997). Levi-Strauss: Empu Antropologi Struktural. terj. Heddy Shri Ahimsa-Putra. Yogyakarta: LKiS.

[12] Pramoedya Ananta Toer (1980). Bumi Manusia. Jakarta: Lentera.

[13] Pramoedya Ananta Toer (1999). Arok-Dedes. Jakarta: Lentera.

[14] Ricklef, M.C. (1991). Sejarah Indonesia Modern. terj. Dharmono Hardjowidjono. Yogyakarta: UGM Press.

[15] Teeuw, A. (1997). Citra Manusia Indonesia dalam Karya Sastra Pramoedya Ananta Toer. Jakarta: Pustaka Jaya. 